\title{
On the Errors of a Time Counting System for Use in Experiments with a Shock Tube*
}

\author{
Matsunosuke IWASAKI**
}

\begin{abstract}
A time counting system for use in a shock tube having an accuracy of 5 counts of $1 \mathrm{Mc} / \mathrm{s}$ pulses are made, and the process of improvement of its accuracy is described.

The development of detached shocks ahead of $180^{\circ}$ and $10^{\circ}$ wedge sections in the transonic region is experimented with the shock tube.
\end{abstract}

\section{Introduction}

With a shock tube, the author has made experiments on the developement of detached shock waves ahead of obstacles in the transonic region. For this purpose a shock tube and measuring apparatuses were made, and some of the results obtained with them were already reported.12,2),3) In the transonic region, however, slight changes in Mach number show a large difference in the test results. For examples, when the Mach number changes by 0.01 , the errors in the distances of shock waves ahead of obstacles are of the order of 10 per cent of $s / t$ for $M=1.15$ and 30 per cent for $M=1.05$. (symbols are illustrated in Figs. 1 (b) and 6)***.

Therefore the accuracy of the measurement of shock velocity in a shock tube gives a very serious influence upon the precision of the experimental results. Accordingly, if we want to obtain experimental results having an accuracy of 10 per cent in the transonic region, we must measure the Mach number in the warm air of a shock tube at least with the accuracy of $\Delta M=0.01$ or 5 counts by using a counter of $1 \mathrm{Mc} / \mathrm{s}$ pulses. (see Fig. 1(a)) Consequently the author tried to make such a counter and other electronic apparatuses for the measurement that could resolve the time of $1 \mu \mathrm{sec}$. But these apparatuses did not show

* Read before the Forum of Traneonic Aerodynamics of the Japan Society of Aeronautical Engineering, Tokyo, Dec. 22, 1957. Received, March 5th, 1957.

** Department of Applied Mechanics, Faculty of Engineering, Kyushu University, Fukuokashi, Japan.

*** These are calculated by the following formula4) $s / t=1.658\left(M^{z}-1\right)^{-\frac{3}{2}}$

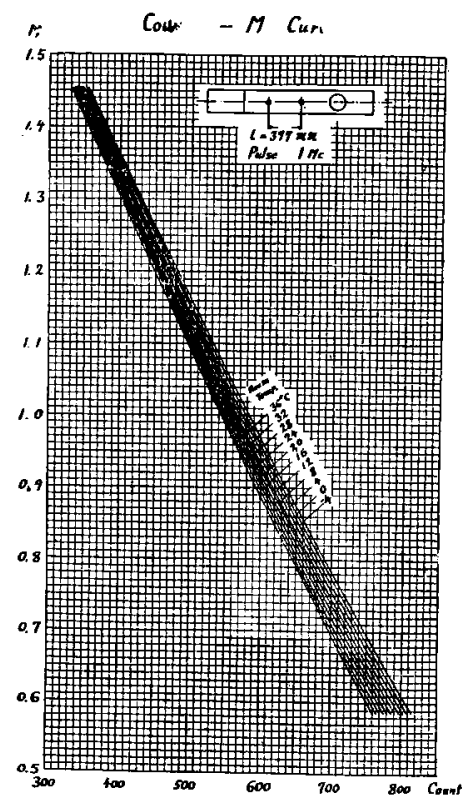

Fig. 1. (a)

the required accuracy, so that the author tried various improvements in them. Finally he obtained the apparatuses which could be considered to have an accuracy of at least 5 counts. Usually, for the measurement with a shock tube, a counter with the resolution time of less than $4 \mu \mathrm{sec}$ is used. As seen from the facts that Geiger's counter $^{5)}$ of résolution time of $1 \mu \mathrm{sec}$ was not entirely satisfactory, and that Tamaki' ${ }^{6}$ and Kawamura $^{\text {p }}$ are using the counters with the resolution time of larger than $2 \mu \mathrm{sec}$, it seems that some problems are still left unsolved for the further investigations. Accordingly, in this paper, the author will report his counting system of resolution time of $1 \mu \mathrm{sec}$. The experiments on the development of detached shock waves in the 


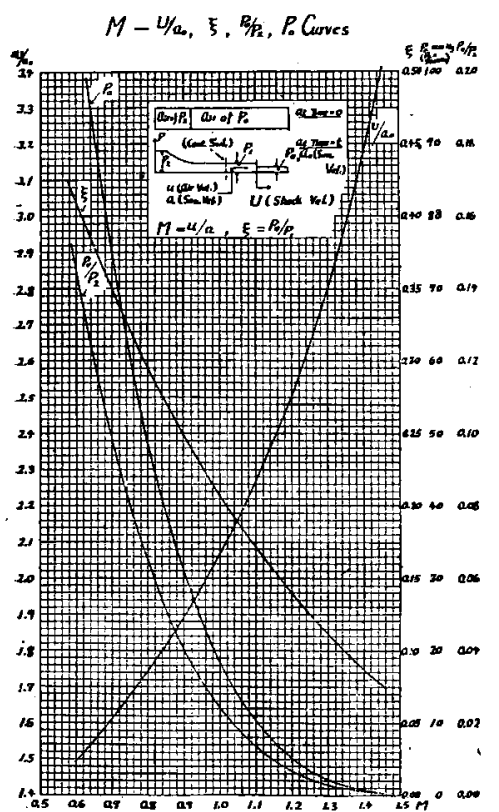

Fig. 1. (b)

transonic region were performed with them, and some results were obtained. These results will

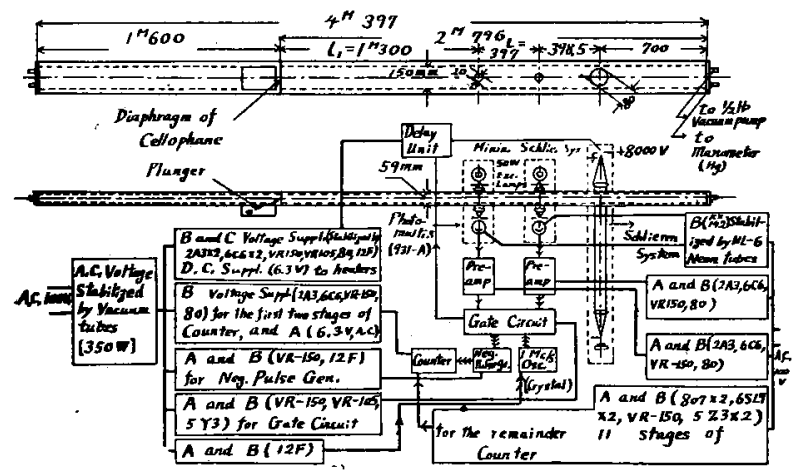

Fig. 2. Shock tube, Schlieren System, Instruments of Measurement and System of Power Supply.

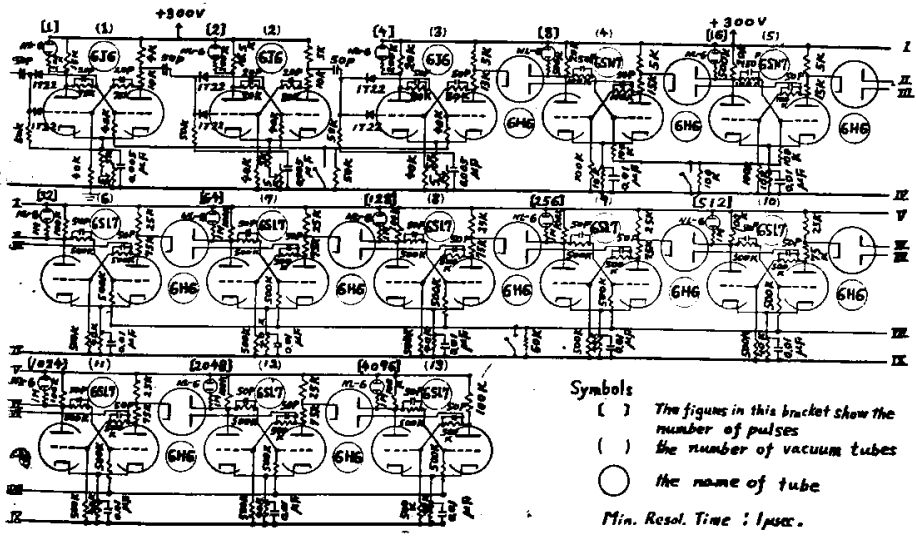

Fig. 3. Electronic Binary Counter. be also stated here.

\section{Shock Tube and Measuring Apparatuses}

In Fig. 2 the shock tube used and block diagrams of the apparatuses are shown. The cross section of the tube is $59 \mathrm{~mm} \times 150 \mathrm{~mm}$, and its lower pressure chamber can be made vacuous down to the pressure of $4 \mathrm{~mm} \mathrm{Hg}$ with a $1 / 2 \mathrm{E}$ vacuum pump. $p_{2}$ is one atmospheric pressure. The duration of the warm air is about $900 \mu$ sec for $M=1.15$. Only the counter and the negative pulse generator of the measuring apparatuses are shown in Figs. 3 and 4. The other circuits were already reported. ${ }^{12,2)}$

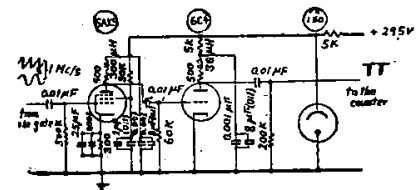

Fig. 4. Negative Pulse Generator.

\section{Discussion on the Measuring Apparatuses} Fis the author stated in the introduction, he must obtain the exact count at least with an accuracy of 5 counts of $1 \mathrm{Mc} / \mathrm{s}$ pulses for the present experiments. But in the earlier stage of his improvement, the counting system did not show a satisfactory performance. After his precise inspection, he found that many improper components for the circuits caused such errors in count as amounted to 30 counts. In distinguishing a correct count from an erroneous one, he had not an absolute standard of the time interval during; which the counter counts the number of $1 \mathrm{Mc} / \mathrm{s}$ pulses. Therefore the author considered that the counter, which satisfied the following conditions as sufficiently as pessible, should be a good counter.

(a) The required good counter must resolute $1 \mathrm{Mc} / \mathrm{s}$ pulses correctly, when the pulses are transmitted to it continuously.

(b) If a delay circuit generates a correctly and steadfastly

(129) 
delayed pulse, the counting system must always show the same count. This count is the one which is counted during the definite interval of time between the start pulse and the delayed stop pulse.

(c) The experimental results measured with the counter must agree with ones obtained by the methods which are usually used in high speed aerodynamics.

(d) A good counter must show stable counts for a long period of time.

The condition (a) was always satisfied in the present apparatuses. This was made sure with a cathode-ray oscillograph and a low frequency oscillator. By checking the other conditions in the same time, however, the author found that some of them were not always satisfied. If there are no self-oscillating parts in the counter system, the cause of this error seems to be due to the fact that the counting system counts less pulses than the true ones. Therefore the errors in count will become smaller by selecting suitable components for the circuits, so that the counts approach to a definite correct ones. Therefore the following improvements were made.

(1) The power supplies of the counting system are shown in Fig. 2. These stabilized power supplies are connected to the measuring units by the thick lines. The important power supplies are connected to the A.C. power supply (100v.) stabilized by means of vacuum-tubes.

(2) The voltage of $+B$ has serious effect on the count. We, after many trials, found the suitable voltages for each units (see Figs. 3 and 4).

(3) The values of resistors which connect the cathodes of $6 \mathrm{~J} 6 \mathrm{~s}$ to the ground are important to the counter. By varying the resistances, the variation in count attains to 5 counts at its maximum. Because this variation is a continuous one, the author cannot determine which is the accurate one among them.

(4) The voltage dividing resistors, which are connected to the anode of the output sides of each tubes of the counter, are divided into the ratio of about 2:1 for the first two stages and
3:1 for the rest of the stages. Too'low ratio will produce errors in count which may amount. to 30 counts.

(5) The grid resistor of the second tube 6C4 of the negative pulse generator (see Fig. 4) is carefully determined. By changing this, the count. changes within the limit of 30 counts.

(6) The vacuum- tubes which are used in the negative pulse generator, the gate tube, which is used in the gate unit, and the tubes for the first three stages of the counter are selected carefully from several new vacuum-tubes.

(7) The photomultipliers (see Fig. 2) must be set in their most sensitive position, which will be known by the colour of the Neon-tubes. These are used to stabilize the power supply to the photomultipliers.

The improper components, which were not. mentioned above, are changed to the proper ones.

Carrying out checks on the counting system. performance, the author found that the present circuits (see Figs. 2, 3, and 4) almost satisfied. all the condítions stated above. Accordingly he considers that these counting apparatuses have an accuracy of at least 5 counts of $1 \mathrm{Mc} / \mathrm{s}$ pulses.

To obtain a better counting system than the present one, the improvements in the negative pulse generator and the gate unit will be important.

4. Experimental Results

(i) Experiment with a wedge section having: its apex angle of $5^{\circ}$ The model is made of mild steel and has the thickness of $6 \mathrm{~mm}$. The experiment was performed in the warm air. This experiment was made to know how closely the Mach number $M_{a p}$ read from the shock angle of the attached oblique shocks agreed with the Mach number $M$ which calculated from the count of the counter. We see in Table 1 that the agreement is fairly well. Considering that ${ }^{5)}$,

Table 1

\begin{tabular}{l|llllll}
\hline$M_{a p}$ & $1.23_{2}$ & 1.22 & $1.19_{5}$ & $1.21_{0}$ & $1.21_{5}$ & $1.20_{0}$ \\
$M$ & $1.22_{6}$ & $1.23_{2}$ & $1.23_{8}$ & $1.21_{4}$ & $1.28_{5}$ & $1.21_{3}$ \\
$D \mu$ sec & 89 & 197 & 298 & 488 & 182 & 170 \\
\hline
\end{tabular}

( $D$ is illustrated in (iii)) 
as Geiger reported, $M_{a p}$ contains considerable errors due to the bluntness of the leading edges of bodies and the boundary layer over the wedges ${ }^{8)}$ in the transonic region, the author connot say that the condition (c) fully satisfied. But this agreement is an evidence for (c).

(ii) Comparison of pressure ratio $p_{2} / p_{0}$ and shock speed $U / a_{0} *$ Fig. 5 shows the results of the present experiment, and those of Kawamura? and Lundquist ${ }^{9}$.

The three results agree fairly well. This is also an evidence of the condition (c).

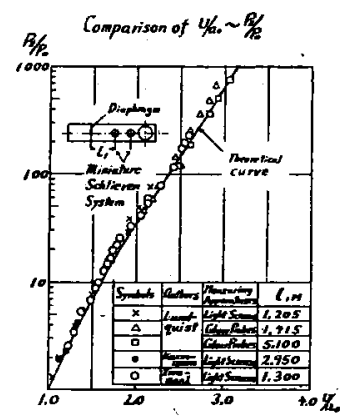

Fig. 5. Comparison of $U / a_{0} \sim P_{2} / P_{0}$

(iii) Experiments of detached shock waves It is the object of the following experiments to obtain a full information about the development of the forms of shock waves ahead of obstacles in the transonic region. In this region, however, a shock tube chokes as the flow around the obstacles becomes stable, so that he cannot obtain the process of development of detached shock waves up. to their final stage. But as the size of models becomes smaller, the choking state will come at comparatively final stage of the development. So that he will be able to obtain almost the entire process of the development with a shock tube. Using smaller models, however, the precise flow field at the beginning of the development becomes more difficult to be seen, so that the author uses various size of models to see all the stages of development with the same accuracy. Now the author will define a time $D$. This is the time duration from the instance when. the shock front of a shock tube reaches just ahead of the model, to the instance at which the electric

* (about symbols, see Fig. 1(b)) quantity of $8,000 \mathrm{~V}$ is discharged to take photographs of flow fields by Shlieren method. It will be reasonable to consider that the flow field at the time $D$ around the body twice as large as the other will be similar to the flow field at the time $D / 2$ around the small size. Therefore, if we use a nondimensional abscissa $D / T_{0}$ and a nondimensional coordinate $s / t$, the results obtained by different size of the similar models will be represented by a single curve, where $T_{0}$ is give by

$$
\begin{aligned}
T_{0}=t / U, t: & \text { thickness of models. } \\
U: & \text { velocity of shock front. } \\
& \text { (The present experiments } \\
& \text { were performed at the } \\
& \text { room temperature of } \\
& \text { about } 9^{\circ} \text { C.). }
\end{aligned}
$$

and

$s:$ the distance of the normal
portions of detached shock
waves measured the from
shoulder of wedge sec-
tions.

Figs. 6, 7, 8 and 9 show the results of experiments analyzed by this method. The thickness of models and the mean Mach number in the warm air in which the experiment were performed are shown in the figures.

The curves of $s / t$ for each experiment follow a common envelope up to some values of $D / T_{0}$, and then they part from this curve. They, afterwards, distorted to be finally destroyed in their forms before the attainment of the contact surface to the test section. The departure of each curve from the envelope may be due to the effect of the wall of the shock tube, because this phenomena appears in earier stage of development for larger models. The envelope of each curves, therefore, will correspond to the location of detached shock waves at each stage of development. Even using the model of $0.6 \mathrm{~mm}$ the locations of detached shock waves do not reach the final stable states. In addition, if $t$ becomes smaller than $0.6 \mathrm{~mm}, s / t$ seems to become larger. Especially this tendency is seen clearly when $M=1.04$. Considering that on the model of $t=0.6 \mathrm{~mm}$ already the effects of the boundary layer and the 


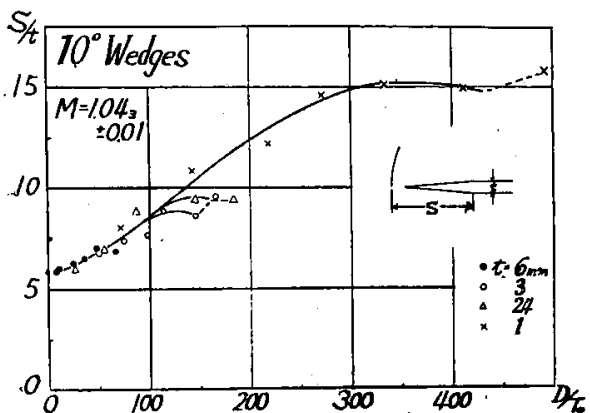

Fig. 6. The Development of Detached Shock Waves

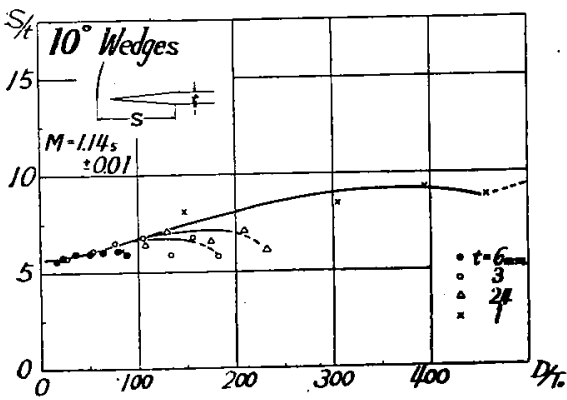

Fig. 7. The Development of Detached Shock Waves.

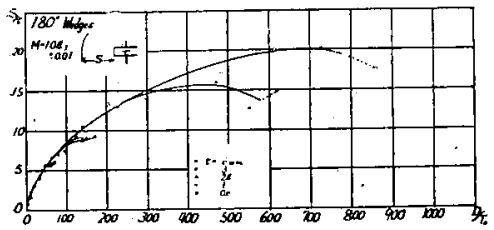

Fig. 8. The Development of Detached Shock Waves.

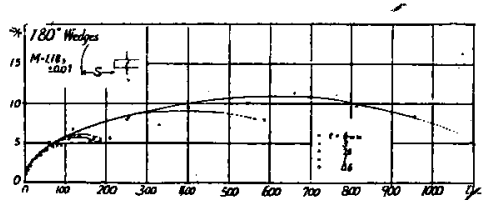

Fig. 9. The Development of Detached Shock Waves.

:support of the model is potent, the experiment by thinner models will produce erroneous results. Accordingly the final positions of detached shock waves may be correspond to the maximum values of the envelopes of $s / t$ curves of the present experiments. These values of $s / t$ are compared in Fig. 10, where the experiment for the point corresponding to $M=1.08$ is not shown in details in this paper. The values of $s / t$ for $10^{\circ}$ and $180^{\circ}$ wedges are almost the same each other for the stages of development at which the comparison

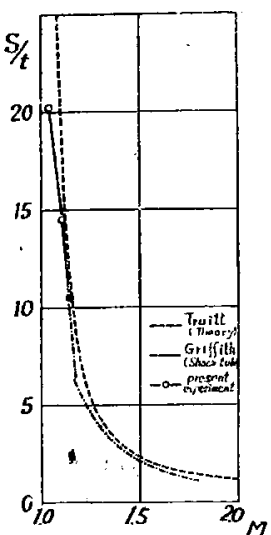

Fig. 10. Comparison of the Ultimate Positions of Detached Shock Waves

is made. Truitt's theoretical value ${ }^{10)}$ and Griffith's experimental one ${ }^{4}$ are also plotted in it. Considering the accuracy of the present experiments the agreement is fairly well. In Fig. 11 the envelopes of $s / t$ curves are compared. We find that, after some duration of time of development, the positions of normal parts of detached shock waves for $10^{\circ}$ and $180^{\circ}$ wedges coincide with each other.

Even considering only the results of experiments stated above, it will be reasonable to think that the counting system has an accuracy of 5 counts of $1 \mathrm{Mc} / \mathrm{s}$ pulses or 0.01 of Mach number.

\section{Conclusions}

(1) The counter and its additional apparatuses which have an accuracy of at least 5 counts are made.

(2) The development of detached shock waves ahead of $10^{\circ}$ and $180^{\circ}$ wedge sections for $M=1.04_{3} \pm 0.01$ and $M=1.14_{5} \pm 0.01$, respectively, are obtained almost up to their final stages of development.

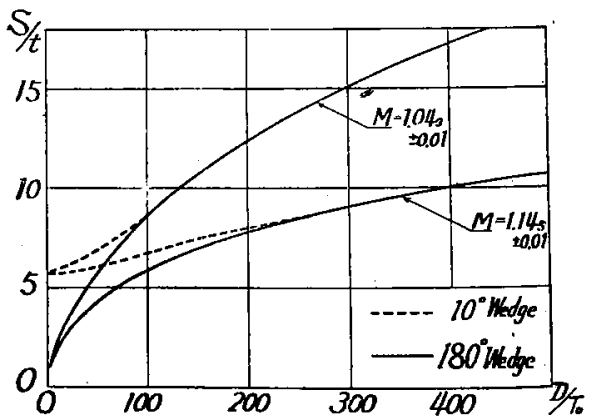

Fig. 11. Comparison of Detached Shock Waves of $10^{\circ}$ and $180^{\circ}$ Wedges. 
The experiments were performed by the aid of the Collective Scientific Research Fund of the Educational Ministry.

The author should like to express his sincere gratitude to Professor H. Sato for his encouragement during this investigation, and to Professor S. Kawada and R. Kawamura of Ins. Sci. Techno. Univ. Tokyo for their valuable suggestions for him. The author is very thankful to Assistant M. Noda for his constant help in the author's work. His thankfulness is also due to K. Umetsu, a post-graduate student, who assisted him in making the experiments and analyzing the results.

\section{References}

1) Iwasaki, M., Nishioka, K., and Iwamura, R.: Trial Manufacture of a shock 'Tube (I) Techno. Rep. Kyushu Univ., Vol. 28, No. 1, (1955/8), p. 8.

2) Iwasaki, M.: Trual Manufacture of a Shoek Tube
(II), Techno. Rep. Kyushu Univ., Vol. 29 No. 1. $(1956 / 6)$, p. 29.

3) Iwasaki, M.: Studies of the Development of Detached Shock Waves in the Transonic Region with a Shock Tube (I). Techno. Rep. Kyushu Univ., Vol. 29. No. 1, (1956/6), p. 22.

4) Griffith, W,: Shock-Tube Studies of Transonic Flow over Wedge Profiles, J. Aero. Sci., Vol. 19, No. $4(1952 / 4)$, p. 249.

5) Geiger, F. and Mautz, C. W.: The Shock Tube as an Instrument for the Investigation of Transonic and Supersonic Flow Patterns, Engineering Research Inst., Univ. Michig., (1949/6).

6) Tamaki, A. and Oshima, K.: Investigation of High Speed Air Flow with a Shock Tube, Res. Produ. (Seisankenkyu), Vol, 5, No. 4, (1953/4), p. 87.

7) Kawamura, R. and Saito, H.: The $5 \times 15 \mathrm{~cm}$ Shock Tube at I.S.T.. Rep. Inst. Sci. Techno. Univ. Tokyo, Vol. 9, No. 4, (1955), p. 73.

8) Liepmann, H.W. and Bryson, A.E.: Transonic Flow Past Wedge Sections, J. Aero. Sci., Vol. 17,. No. 12, (1950/12), p. 745 .

9) Lundquist, G. A.: Shock Wave Formation in a Shock Tube, T. Appl. Phys., Vol. 23, No. 3, (1952/3), p. 374 .

10) Truitt, R.W.: A Method for Location of Detached Shock Waves Ahead of Plane Bodies, J. Aero. Sci., Vol. 20, No. 1, $(1953 / 1)$, p. 61 .

高速流体力学, 河村竟馬, 工業物理学講座

高速流体力学は戦中，戦後急速に発展し，すでに完 成された特有の体系をもつに至っている．したがって 海外ては現在この方面の成書はちょっと思い禘ぶもの だけでも十指に余るほど出揃っている. 何といっても これからの航空の中心課題の一つであるし，日本であ そろそろをとまった本がほしいと思っていた矢先，今 回河村氏の標記の著書か泏版された。同氏は人も知る 空力の第一線研究者，また優れた綜合報告の著者でも あるのでこの本覀かろうはずがない、ただ惜しむら くは講座特殊編の一冊ということで紙数が題目に対し てやや與屈たあったことである。

したがって内容が完全流体の定常的な业音速，超音

速，遷音速の流れの取扱いに限られたのはやむを得な。 い.それでもこの分野，とくに超音速流の理論に今日 までの高速流体力学の最も大きい成果が含まれてお り，本書の重点もまたここに置かれているのは賛成で ある. 全般に基礎的な概念抢よび方法について，かみ くだいた説明が親しみやすく述べられて居りとくに， うっかり見逃してしまら要点，誤解しやすい個所につ. いて所々貴重な注意が与えてあるのむ親切で気持がよ い.三次元翼理論と遷音速流のくだりはやや馳足気味 なので初めての人には多少息が切れるかもしれない。 しかしとにかくこれで日本にも標準的なテキストが一。 つ生れたのはうしれいことである。

本書は応用面に対する配慮む充分なされているのて 実際家にむ満足のゆく参考書となるであろう。

(玉田 牫) 